Published in final edited form as:

J Am Chem Soc. 2004 November 17; 126(45): 14720-14721.

\title{
Total Synthesis of Kendomycin: A Macro-C-Glycosidation
}

\section{Approach}

\author{
Yu Yuan, Hongbin Men, and Chulbom Lee \\ Department of Chemistry, Princeton University, Princeton, New Jersey 08544-1009
}

Kendomycin (1), also known as (-)-TAN 2162, is a novel ansamycin isolated from various Streptomyces species. ${ }^{1,2}$ It is a potent antagonist of the endothelin receptor and a calcitonin receptor agonist that functions as an anti-osteoporotic agent. ${ }^{1}$ In addition to these modulatory roles on cellular receptors, this bacterial metabolite also displays strong antibiotic activities against a wide range of bacteria, including MRSA strains. ${ }^{2}$ Furthermore, kendomycin possesses remarkable cytostatic effects on the growth of several human cancer cell lines with a potency higher than or comparable to that of some clinically used drugs. ${ }^{2}$ Structurally, kendomycin represents a unique ansa system in which a densely substituted tetrahydropyran ring is directly attached to the quinone methide chromophore within a macrocyclic scaffold. This fully carbogenic ansa framework is unprecedented among all of the ansamycins isolated so far. ${ }^{3}$ Thus, the novel molecular architecture, along with the impressive biological profile, renders kendomycin an important subject of bio- ${ }^{2}$ and chemical ${ }^{4,5}$ synthetic studies. Described herein is the first enantioselective total synthesis of kendomycin (1).

From a synthetic viewpoint, the $\mathrm{C} 13-\mathrm{C} 14$ bond offers an attractive handle for macrocyclization by a ring-closing olefin metathesis (RCM) reaction. However, the trisubstitution and $(E)$ geometry of this alkene cast uncertainties as to the efficacy of this approach. Moreover, Mulzer and co-workers have noted a hindered rotation about the $\mathrm{C} 4 \mathrm{a}-\mathrm{C} 5$ bond in their advanced synthetic intermediates, ${ }^{4}$ which might prove prohibitive for an RCM strategy. Our approach is based on the idea that the very $\mathrm{C} 4 \mathrm{a}-\mathrm{C} 5$ bond that causes atropisomerism might be formed by a ring closure, thereby avoiding complications arising from the conformational issues (Scheme 1). Hence, the challenge of constructing a macrocycle and the ansa bridge could be simultaneously reduced to a potentially more manageable problem of an aryl $C$-glycoside synthesis. ${ }^{6}$ Our synthetic plan projects a late stage fashioning of the ansa core by an oxidative hydration of benzofuran $(\mathbf{3} \rightarrow \mathbf{2} \rightarrow \mathbf{1})$. The secomacrocycle $\mathbf{4}$ is envisioned to be assembled by the union of two subunits, $\mathbf{5}$ and $\mathbf{6}$, of roughly equal complexity, which in turn can be prepared from readily available building blocks.

E-mail: cblee@princeton.edu

Supporting Information Available: Experimental details and spectral data for all new compounds. This material is available free of change via Internet at http://pubs.acs.org. 


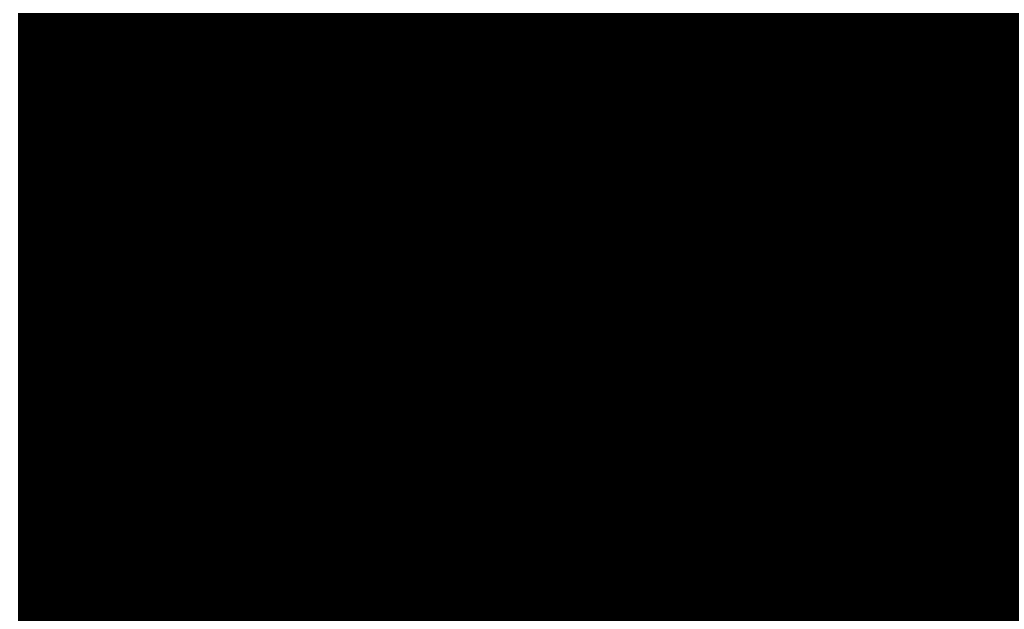

\section{Scheme 1.}

Structure and Retrosynthetic Analysis of Kendomycin

The synthesis of the tetrahydropyranyl subunit $\mathbf{5}$ employed chiral enolate chemistry to establish the key bonds and stereogenic centers (Scheme 2). The route commenced with the alkylation of Myers' amide 7 with iodide 8, which set the $\mathrm{C} 12$ stereocenter. ${ }^{7}$ After reductive detachment of the chiral auxiliary, the resulting aldehyde $\mathbf{9}$ was advanced to $\mathbf{1 0}$ by alkynylation 8 of the aldehyde and oxidation ${ }^{9}$ of the desilylated alcohol. The THP ring, adorned with contiguous stereogenic centers, was then constructed through a sequence involving stereoselective aldolation, reduction, and lactonization. ${ }^{10}$ The sequential hydrostannylation-iodination of 13 was carried out with high regioselectivity to afford subunit 5 . $^{11}$

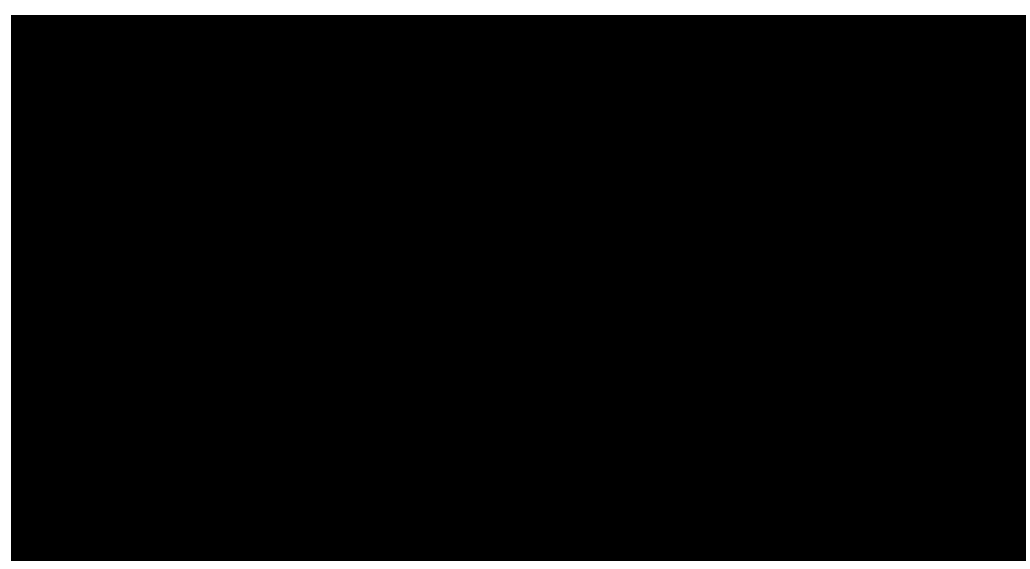

Scheme 2.

Synthesis of the Tetrahydropyran Domain ${ }^{\mathrm{a}}$

${ }^{a}$ Reagents and conditions: (a) ref ${ }^{7}$; (b) (i) $\mathrm{CBr}_{4}, \mathrm{PPh}_{3}, \mathrm{Zn}, \mathrm{DCM}, 83 \%$, (ii) $n$-BuLi, MeI, THF, $99 \%$, (iii) TBAF, THF, 99\%, (iv) Dess-Martin, DCM, 85\%; (c) Sn(OTf) 2 TEA, DCM, $-78^{\circ}$ C, $82 \%$ (dr = 7:1); (d) (i) $\mathrm{NaBH}(\mathrm{OAc})_{3}, \mathrm{AcOH}, 5{ }^{\circ} \mathrm{C}, 84 \%$ (dr = 20:1), (ii) DBU, DCM, 90\%; (e) (i) cat. $\mathrm{Pd}(\mathrm{OAc})_{2}-\mathrm{PCy}_{3}, n-\mathrm{Bu}_{3} \mathrm{SnH}$, hexanes-THF, (ii) $\mathrm{I}_{2}, \mathrm{DCM}, 83 \%$ (dr = 7-10:1). 


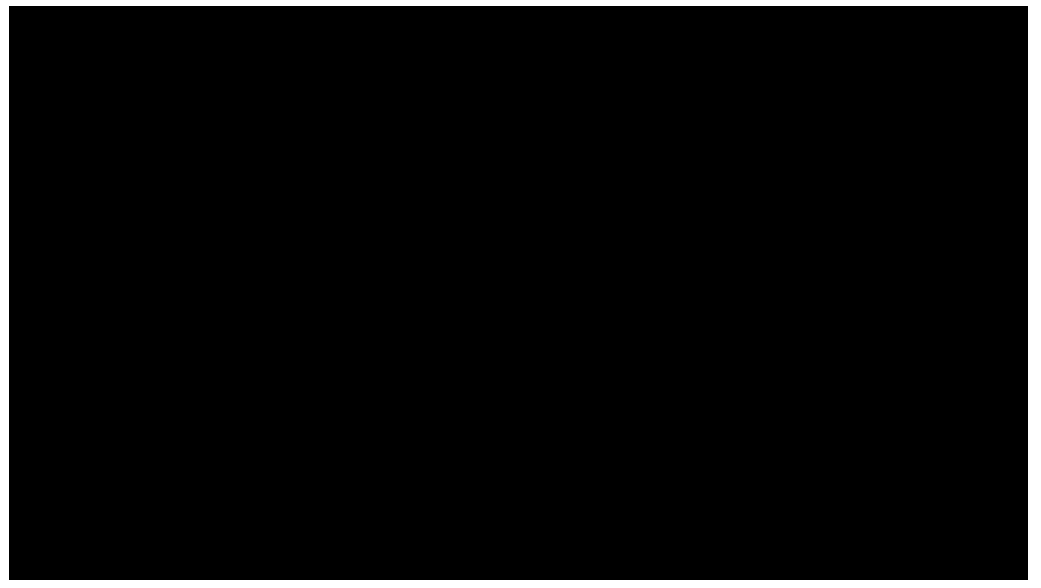

Scheme 3.

Synthesis of the Benzofuran Domain ${ }^{\mathrm{a}}$

${ }^{a}$ Reagents and conditions: (a) (i) TBSCl, imidazole, DCM, (ii) Dibal-H, DCM, $-78{ }^{\circ} \mathrm{C}, 95 \%$;

(b) $\mathrm{Ph}_{3} \mathrm{P} \cdot \mathrm{HBr}, \mathrm{CH}_{3} \mathrm{CN}, 78 \%$; (c) DCC/DMAP, DCM, then TEA, toluene, reflux, 93\%; (d) (i) $10 \mathrm{~mol} \% \mathrm{Pd} / \mathrm{C}, \mathrm{H}_{2}$, EtOAc- $\mathrm{CH}_{3} \mathrm{OH}, 99 \%$, (ii) $\mathrm{I}_{2} / \mathrm{PPh}_{3}$, imidazole, DCM, $96 \%$.

Having defined a route to $\mathbf{5}$, we turned to the synthesis of the benzofuranyl domain using a two-stage condensation approach (Scheme 3). ${ }^{12}$ Thus, the phenolic phosphonium bromide 16 was prepared from the known aldehyde $\mathbf{1 4}^{13}$ by selective silylation, reduction, and addition of $\mathrm{HBr} \cdot \mathrm{PPh}_{3} \cdot{ }^{14}$ The sequential esterification and Wittig processes merged 16 and $17^{15}$ smoothly to give benzofuran 19 in high yield. ${ }^{12}$ Finally, removal of the benzyl group followed by iodination of the exposed hydroxyl group furnished the desired alkyl iodide $\mathbf{2 0}$.
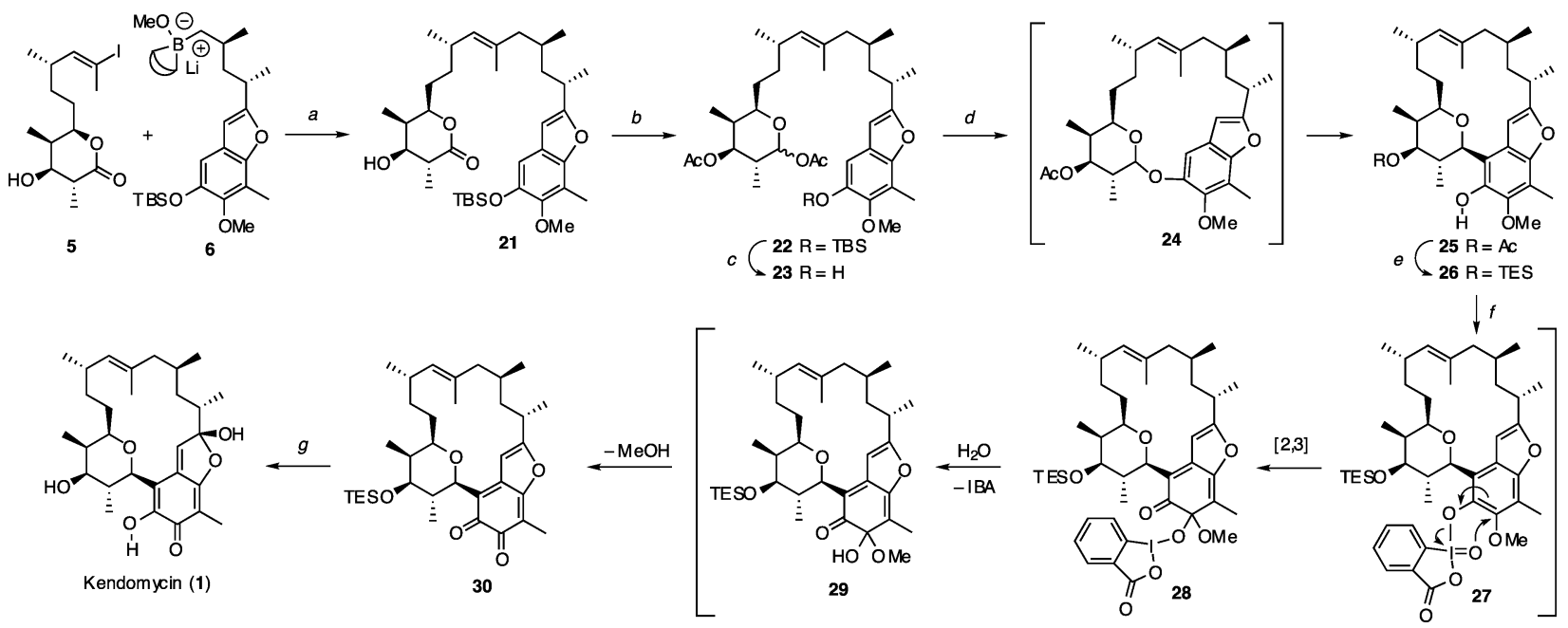

Scheme 4.

Suzuki-Miyaura Merger of the Key Fragments, Macroglycosidation, and Completion of the Total Synthesis of Kendomycin (1) ${ }^{\mathrm{a}}$

${ }^{a}$ Reagents and conditions: (a) $4 \% \mathrm{PdCl}_{2}$ (dppf), $3 \mathrm{M}$ aq $\mathrm{K}_{3} \mathrm{PO}_{4}, \mathrm{Et}_{2} \mathrm{O}-\mathrm{THF}-\mathrm{DMF}$, 86\%; (b)

Dibal-H, toluene, then $\mathrm{Ac}_{2} \mathrm{O}$, pyridine, 79\%; (c) TBAF, THF, 91\%; (d) $\mathrm{SnCl}_{4}, 4 \AA \mathrm{MS}, \mathrm{CHCl}$ 3, 40-70\%; (e) (i) MeONa/MeOH, 87\%, (ii) TESOTf, Et ${ }_{3} \mathrm{~N}, \mathrm{DCM}, 98 \%$; (f) IBX, DMF, $62 \%$ (g) aq $\mathrm{HF}, \mathrm{CH}_{3} \mathrm{CN}, 50 \%$.

With the procurement of the two fragments, the feasibility of their union through $\mathrm{C} 14-\mathrm{C} 15$ bond formation was probed (Scheme 4). Under the Pd-catalyzed conditions, ${ }^{16}$ boranate $\mathbf{6}$, which was prepared from 20 by lithiation and transmetalation $(t-\mathrm{BuLi}$, ether, then $B-\mathrm{OMe}-9$ - 
BBN), participated well in the cross-coupling reaction with iodide $\mathbf{5}$ to provide alkene $\mathbf{2 1}$ in excellent yield. To this intermediate containing all of the carbon atoms of kendomycin was imparted a glycosyl donor function by converting it into anomeric acetate $\mathbf{2 2}$, thus setting the stage for the macro aryl $C$-glycosidation. Our initial attempts to cyclize 22 under a variety of Friedel-Crafts conditions were unsuccessful, mainly leading to hydrolysis of the anomeric acetate. ${ }^{17}$ In contrast, the reaction employing phenol $\mathbf{2 3}$ as the substrate occurred smoothly to afford the desired macrocycle $\mathbf{2 5}$ as a single stereoisomer in $40-70 \%$ yield. As a nonpolar product was produced rapidly at $-5{ }^{\circ} \mathrm{C}$, which turned into 25 at room temperature over $12 \mathrm{~h}$, this reaction appeared to proceed through facile formation of $O$-glycoside 24 and subsequent rearrangement to $C$-glycoside $25 .{ }^{18}$ After exchange of the $C 7$ protecting groups, oxidative fashioning of the aryl core was achieved by careful treatment of $\mathbf{2 6}$ with IBX, which formed the unstable diketone 30. ${ }^{19}$ Monitoring this reaction by ${ }^{1} \mathrm{H}$ NMR revealed the intermediacy of mixed ketal 28, which underwent slow hydrolysis to 29 and eventually to $\mathbf{3 0}$. The removal of the TES group and hydration of the ortho-quinone by the action of aqueous HF finally produced kendomycin (1). Synthetic kendomycin exhibited physical and spectroscopic characteristics $\left(R_{f}, \mathrm{mp},[\alpha]_{\mathrm{D}}, \mathrm{IR},{ }^{1} \mathrm{H},{ }^{13} \mathrm{C} \mathrm{NMR}\right.$, and HRMS $)$ identical to those reported for the natural product.

In summary, the first total synthesis of kendomycin has been achieved. Notable features of the synthesis are high levels of convergence and stereocontrol in the assembly of key subunits, efficient establishment of the structural core by a macroglycosidation, and a novel oxidative hydration strategy to construct the ansa chromophore.

\section{Supplementary Material}

Refer to Web version on PubMed Central for supplementary material.

\section{Acknowledgment}

The authors gratefully acknowledge Princeton University for startup funding. Y.Y. thanks FMC corporation for a graduate fellowship.

\section{References}

1. Funahashi, Y.; Kawamura, N.; Ishimaru, T. JP Patent 08231551 [A296090]. 1996. Su, MH.; Hosken, MI.; Hotovec, BJ.; Johnston, TL. US Patent 5728727 [A980317]. 1998.

2. (a) Bode HB, Zeeck A. J. Chem. Soc., Perkin Trans 2000;1:323. (b) Bode HB, Zeeck A. J. Chem. Soc., Perkin Trans 2000;1:2665.

3. Funayama, S.; Cordell, GA. Studies in Natural Products Chemistry. Atta-ur-Rahman, editor. 23. Elsevier; New York: 2000. p. 51-106.

4. (a) Martin HJ, Drescher M, Kaählig H, Schneider S, Mulzer J. Angew. Chem., Int. Ed 2001;40:3186. (b) Marques MMB, Pichlmair S, Martin HJ, Mulzer J. Synthesis 2002:2766. (c) Pichlmair S, Marques MMB, Green MP, Martin HJ, Mulzer J. Org. Lett 2003;5:4657. [PubMed: 14627408] (d) Mulzer J, Pichlmair S, Green MP, Marques MMB, Martin HJ. Proc. Natl. Acad. Sci. U.S.A 2004;101:11980. [PubMed: 15277689]

5. Sengoku T, Arimoto H, Uemura D. Chem. Commun 2004:1220.

6. (a) Jaramillo C, Knapp S. Synthesis 1994:1.For reviews, see:Postema, MHD. C-Glycoside Synthesis. CRC; Boca Raton, FL: 1995.

7. (a) Myers AG, Yang BH, Chen H, Gleason JL. J. Am. Chem. Soc 1994;116:9361. (b) Myers AG, Yang BH, Chen H, McKinstry L, Kopecky DJ, Gleason JL. J. Am. Chem. Soc 1997;119:6496.

8. Corey EJ, Fuchs PL. Tetrahedron Lett 1972;13:3769.

9. Dess DB, Martin JC. J. Org. Chem 1983;48:4155. 
10. (a) Evans DA, Clark JS, Metternich R, Novack VJ, Sheppard GS. J. Am. Chem. Soc 1990;112:866. (b) Evans DA, Cee VJ, Smith TE, Fitch DM, Cho PS. Angew. Chem., Int. Ed 2000;39:2533. (c) Evans DA, Fitch DM, Smith TE, Cee VJ. J. Am. Chem. Soc 2000;122:10033.Ref 4b,d

11. Semmelhack MF, Hooley RJ. Tetrahedron Lett 2003;44:5737.

12. Hercouet A, Lecorre M. Tetrahedron Lett 1979;20:2145.

13. Siddiqi SA, Heckrodt TJ. Z. Naturforsch. B 2003;58:328.

14. Hercouet A, Lecorre M. Tetrahedron 1981;37:2867.

15. Vong BG, Abraham S, Xiang AX, Theodorakis EA. Org. Lett 2003;5:1617. [PubMed: 12735735] See Supporting Information for the synthesis acid $\mathbf{1 7}$

16. (a) Miyaura N, Suzuki A. Chem. Rev 1995;95:2457. (b) Marshall JA, Johns BA. J. Org. Chem 1998;63:7885.

17. (a) Chen M, Guzei I, Rheingold AL, Gibson HW. Macromolecules 1997;30:2516.For a rare example of macrocyclization via a Friedel-Crafts acylation reaction, see: (b) Stoddart JF, Nepogodiev SA, Gattuso G. Chem. Rev 1998;98:1919. [PubMed: 11848953]For a macro-O-glycosidation to prepare cyclodextrins, see:

18. Matsumoto T, Katsuki M, Suzuki K. Tetrahedron Lett 1988;29:6935.

19. (a) Magdziak D, Rodriguez AA, Van De Water RW, Pettus TRR. Org. Lett 2002;4:285. [PubMed: 11796071] (b) Ozanne A, Pouységu L, Depernet D, François B, Quideau S. Org. Lett 2003;5:2903. [PubMed: 12889904] 